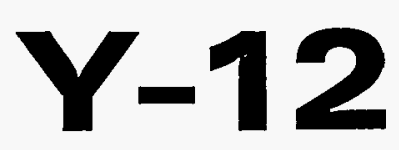

\section{OAK RIDGE$$
Y-12
$$$$
\text { PLANT }
$$

MARTIW' MARUETRA

\section{EVALUATION OF IRON IN THE STEAM PLANT WASTEWATER TREATMENT FACILITY EFFLUENT}

\author{
P. J. Wempner \\ Mid-West Technical
}

J. K. Prazniak

Y-12 Energy Systems

Waste Management Organization

\section{December 1994}

MANAGED BY

MARTIN MARIETTA ENERGY SYSTEMS, INC.

FOR THE UNITED STATES

DEPARTMENT OF ENERGY

\author{
Oak Ridge Y-12 Plant \\ Oak Ridge, Tennessee 37831 \\ managed by \\ Martin Marietta Energy Systems, Inc. \\ for the \\ U.S. Department of Energy \\ under contract DE-AC05-84OR21400
}




\section{DISCLAIMER}

This report was prepared as an account of work sponsored by an agency of the United States Government. Neither the United States Government nor any agency thereof, nor any of their employees, makes any warranty, express or implied, or assumes any legal liability or responsibility for the accuracy, completeness, or usefulness of any information, apparatus, product, or process disclosed, or represents that its use would not infringe privately owned rights. Reference herein to any specific commercial product, process, or service by trade name, trademark, manufacturer, or otherwise, does not necessarily constitute or imply its endorsement, recommendation, or favoring by the United States Government or any agency thereof. The views and opinions of authors expressed herein do not necessarily state or reflect those of the United States Government or any agency thereof. 


\section{DISCLAIMER}

Portions of this document may be illegible electronic image products. Images are produced from the best available original document. 


\title{
EVALUATION OF IRON IN THE STEAM PLANT WASTEWATER TREATMENT \\ FACILITY EFFLUENT
}

\author{
P. J. Wempner \\ Mid-West Technical \\ J. K. Prazniak \\ Y-12 Energy Systems \\ Waste Management Organization
}

December 1994

Oak Ridge Y-12 Plant

Oak Ridge, Tennessee 37831 managed by

Martin Marietta Energy Systems, Inc.

for the

U.S. Department of Energy

under contract DE-AC05-84OR21400 
TABLE OF CONTENTS

Page

1.0 OBJECTIVE $\ldots \ldots \ldots \ldots \ldots \ldots \ldots \ldots \ldots \ldots \ldots \ldots \ldots \ldots \ldots \ldots \ldots \ldots \ldots \ldots$

2.0 METHODS $\ldots \ldots \ldots \ldots \ldots \ldots \ldots \ldots \ldots \ldots \ldots \ldots \ldots \ldots \ldots \ldots \ldots \ldots \ldots \ldots$

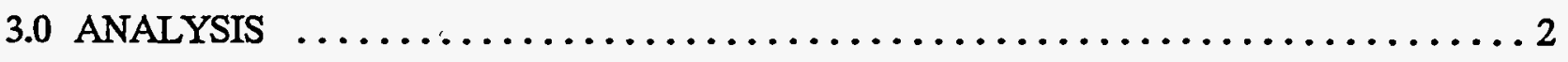

4.0 CONCLUSIONS $\ldots \ldots \ldots \ldots \ldots \ldots \ldots \ldots \ldots \ldots \ldots \ldots \ldots \ldots \ldots \ldots \ldots \ldots$

5.0 RECOMMENDATIONS $\ldots \ldots \ldots \ldots \ldots \ldots \ldots \ldots \ldots \ldots \ldots \ldots \ldots \ldots \ldots$

6.0 REFERENCES $\ldots \ldots \ldots \ldots \ldots \ldots \ldots \ldots \ldots \ldots \ldots \ldots \ldots \ldots \ldots \ldots \ldots \ldots \ldots$ 


\subsection{OBJECTIVE}

This study was undertaken by Oak Ridge Y-12 Plant personnel to identify the root causes of elevated iron concentrations discharged from the Steam Plant Wastewater Treatment Facility (SPWTF). The SPWTF effluent is permitted to discharge up to $1.0 \mathrm{mg} / \mathrm{L}$ of iron. Effluent from the facility, which is sampled three times per week, has exceeded the $1.0 \mathrm{mg} / \mathrm{L}$ limit on 14 occasions since the facility began operation in February of 1988 :

\subsection{METHODS}

Before scrutinizing the SPWTF systems for upgrades, a clear picture of the wastewater chemistry at key locations in the treatment process was developed. Sample points were selected where the response of the key process parameters to step changes in process conditions could be evaluated. Care was taken to obtain samples under steady-state conditions within a reasonable period of time, usually less than 1-1/2 hours. However, because of plant control fluctuations and steam plant discharges, wastewater chemistry changes represented a potential influence on results. Samples were drawn from the following points in the specified order to maximize analytical linkage: SPWTF influent, clarifier effluent, SPWTF effluent. No observable qualitative data indicated that perturbations in system chemistry affected this study.

One hypothesis concerning the cause of poor iron removal is that inadequate aeration before or during treatment allows ferrous iron, $\mathrm{Fe}(\mathrm{II})$, to pass through the process before being converted to the more reactive ferric iron, Fe(III). Samples were obtained from the sample points listed above and were tested for total iron and ferrous iron using a Hach DR-700 colorimeter to determine the extent to which ferrous iron is present under different plant conditions.

Another hypothesis suggests that iron could be carried through the system as solids, bound or unbound by polymer. To test this theory, total iron concentrations present in filtered versus unfiltered samples were compared. The filtered samples were evaluated to determine the dissolved concentrations of all iron species and of $\mathrm{Fe}(\mathrm{II})$. The unfiltered samples were treated with $1 \mathrm{~N}$ nitric acid to a pH of 2.5-2.7 to dissolve any metal in solid form and were then analyzed to determine total iron.

The colorimetric reagent contains a buffer which lowers sample $\mathrm{pH}$ to approximately $\mathrm{pH}$ 4. Because ferric hydroxide is only slightly soluble at $\mathrm{pH} 4$ or greater (see Figure 1), further $\mathrm{pH}$ adjustment using nitric acid was necessary to further dissolve any residual iron and obtain more accurate sample results.

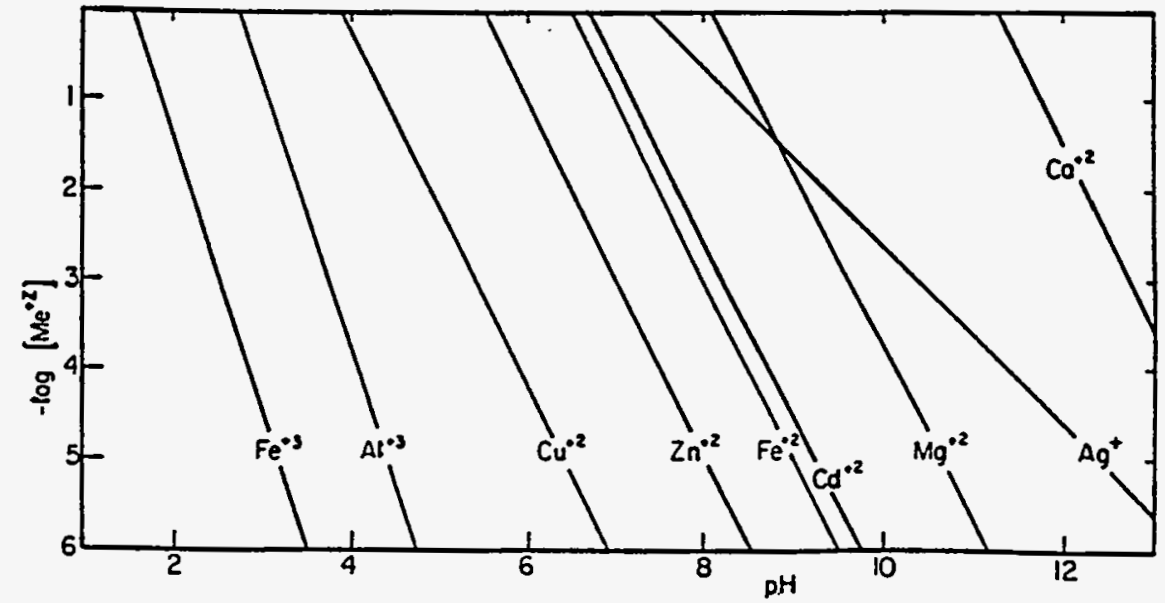

Figure 1. Solubility of oxides and hydroxides. Free metal-ion concentration in equilibrium with solid oxides or hydroxides (1).

Because the solubility of the ions of interest is sensitive to $\mathrm{pH}$ and sludge solubility is also strongly dependent on $\mathrm{pH}$, the $\mathrm{pH}$ of all samples was also recorded. 


\subsection{ANALYSIS}

Five series of sample results are presented herein. The five sample periods represent as diverse atmospheric conditions (e.g., rain, clear/sunny, and cold) as the study period permitted. Conditions were as follows:

Series 1: $44-70^{\circ} \mathrm{F}$, Rain: Trace, Partly Cloudy

Series 2: $48-73^{\circ} \mathrm{F}$, Rain: 0.06 in., Clear/Partly Cloudy

Series 3: $38-59^{\circ} \mathrm{F}$, Rain: None, Clear

Series 4: $27-50^{\circ} \mathrm{F}$, Rain: None, Clear

Series 5: $33-58^{\circ} \mathrm{F}$, Rain: 1.23 in., Cloudy/Clearing

The results from the five sample series are generally indicative of other data taken under similar conditions. The $\mathrm{Fe}$ (II) removal effectiveness for the SPWTF system is depicted in Table I for the five sets of conditions.

\begin{tabular}{|c|c|c|c||}
\hline SERIES & $\begin{array}{c}\text { INFLUENT } \\
\text { Fe(II) }\end{array}$ & $\begin{array}{c}\text { CLARIFIER } \\
\text { EFFLUENT } \\
\text { Fe(II) }\end{array}$ & $\begin{array}{c}\text { EFFLUENT } \\
\text { Fe(II) }\end{array}$ \\
\hline \hline 1 & 0.16 & 0.01 & 0.01 \\
\hline 2 & 0.20 & 0.00 & 0.00 \\
\hline 3 & 2.70 & 0.01 & 0.01 \\
\hline 4. & 0.00 & 0.00 & 0.01 \\
\hline 5 & 1.08 & 0.01 & 0.01 \\
\hline
\end{tabular}

Table I. Fe(I) Removal for Five Sets of Process Conditions (concentrations in $\mathbf{m g} / \mathbf{L}$ )

The data in Table I reveals that effectively all Fe(II) was removed in the SPWTF process under all conditions, though condition 4 was inconclusive. The highest $\mathrm{Fe}(\mathrm{II})$ concentration in any effluent sample was $0.07 \mathrm{mg} / \mathrm{L}$. The data contradicts the assertion that lack of aeration allows ferrous iron to contribute to elevated iron levels in the SPWTF effluent. To the contrary, the data suggests that under most influent conditions $\mathrm{Fe}$ (II) is readily removed from wastewater independent of oxidation to more reactive $\mathrm{Fe}(\mathrm{III})$. The mechanism for $\mathrm{Fe}$ (III) removal is reaction of $\mathrm{Fe}$ (II) to ferrous hydroxide, $\mathrm{Fe}(\mathrm{OH})_{2}$. Under alkaline conditions, $\mathrm{Fe}(\mathrm{OH})_{2}$ is precipitated from the SPWTF wastewater. 
Figure 2 graphically represents conditions favoring the formation of solid $\mathrm{Fe}(\mathrm{OH})_{2}$ in an oxygendeficient solution. By maintaining $\mathrm{pH}$ greater than 10 , ferrous iron concentration should be less than $1.0 \mathrm{mg} / \mathrm{L}$ (4.74 on the ordinate of Figure 2), provided that the solid $\mathrm{Fe}(\mathrm{OH})_{2}$ is removed prior to readjusting $\mathrm{pH}$ downward. Because the clarifier removes solids from solution, alkaline $\mathrm{pH}$ must be maintained throughout the clarifier. During this study, the lowest $\mathrm{pH}$ measured at the clarifier effluent was 10.2.

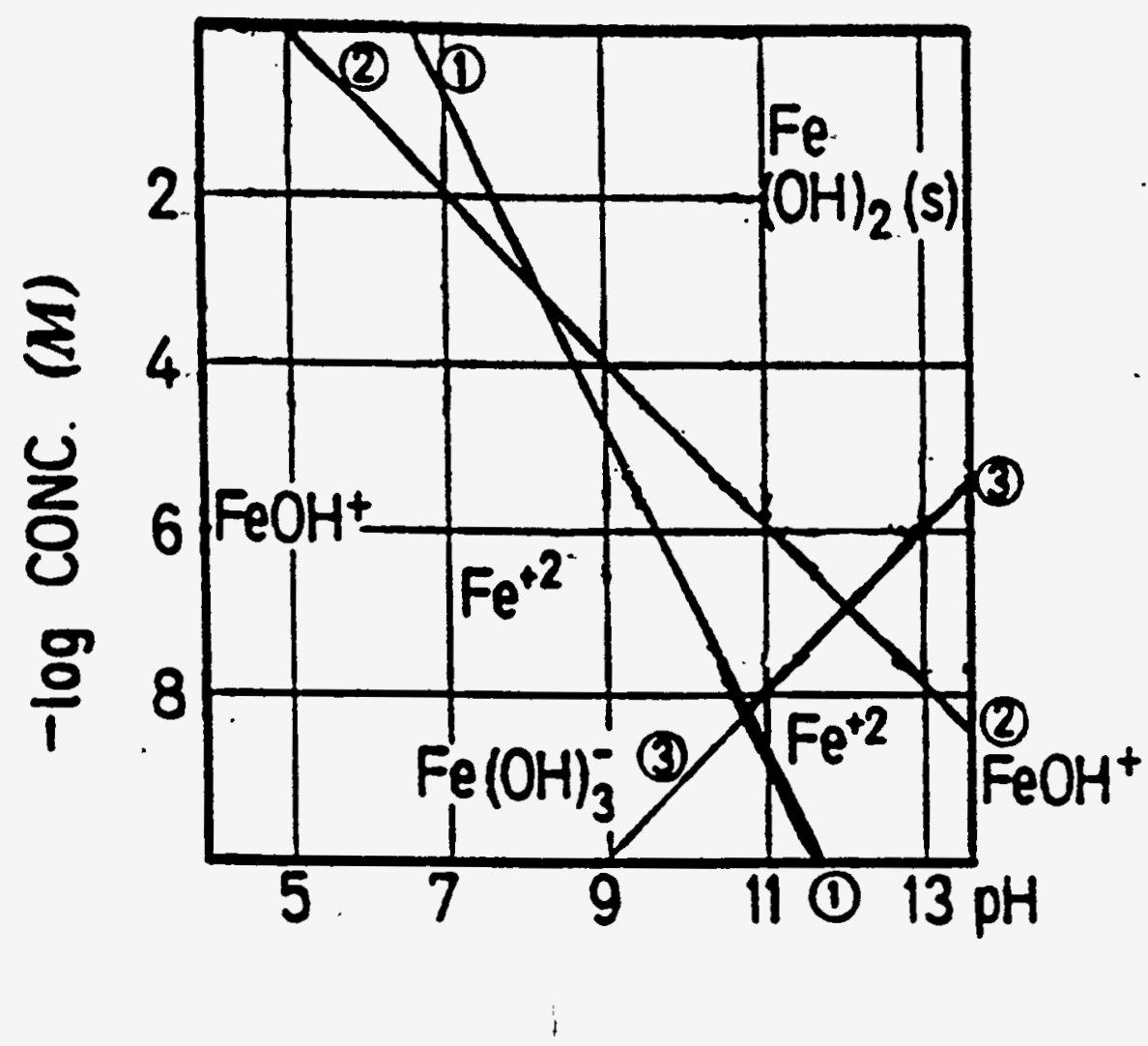

Figure 2. Stability of $\mathrm{Fe}(\mathrm{OH})_{2}(\mathrm{~S})$ and predominate ionic species in closed systems. The numbered lines represent equilibria as follows(1):

$$
\begin{array}{ll}
1 & \mathrm{Fe}(\mathrm{OH})_{2}(\mathrm{~S})=\mathrm{Fe}^{2+}+2 \mathrm{OH}^{-} \\
2 & \mathrm{Fe}(\mathrm{OH})_{2}(\mathrm{~S})=\mathrm{Fe}(\mathrm{OH})^{+}+\mathrm{OH}^{-} \\
3 & \mathrm{Fe}(\mathrm{OH})_{2}(\mathrm{~S})+\mathrm{OH}^{-}=\mathrm{Fe}(\mathrm{OH})_{3}^{-}
\end{array}
$$

The investigation of the second hypothesis-that solids containing iron are not effectively removed but are carried through the treatment process and discharged-was performed using filtration studies. Table II is a comparison of total iron (including iron in solid form) versus dissolved iron at the three sample locations. The dissolved iron is present primarily as ionic $\mathrm{Fe}$ (II) and $\mathrm{Fe}$ (III) species. The contrast between the results for total iron versus dissolved iron in Table II shows that much of the iron present in the wastewater is in solid form. 
The total iron in the plant effluent was consistently higher than the total iron in the effluent from the clarifier. Several explanations for this phenomenon exist. A test of the sulfuric acid used to adjust $\mathrm{pH}$ in the F-2 tank indicated that the acid may contribute up to $0.1 \mathrm{mg} / \mathrm{L}$ of iron to the effluent. However, whether the iron contributed by the acid is ultimately dissolved or solid is uncertain because the iron may further react and change phase in the F-2 tank. Since grab samples of plant effluent are obtained at the effluent weir, elevated iron concentrations could also result from accumulated solids or algal growth in the discharge line and weir. Visual observations of solids that frequently appear at the effluent weir but not in the F-2 tank support this theory.

\begin{tabular}{||c||c|c|r|r||r|r||}
\hline \hline \multirow{2}{*}{ SERIES } & \multicolumn{2}{c|}{$\begin{array}{c}\text { PLANT } \\
\text { INFLUENT }\end{array}$} & \multicolumn{2}{c||}{$\begin{array}{c}\text { CLARIFIER } \\
\text { EFFLUENT }\end{array}$} & \multicolumn{2}{|c||}{ PLANT EFFLUENT } \\
\cline { 2 - 8 } & Total Iron & $\begin{array}{c}\text { Dissolved } \\
\text { Iron }\end{array}$ & Total Iron & $\begin{array}{c}\text { Dissolved } \\
\text { Iron }\end{array}$ & Total Iron & $\begin{array}{c}\text { Dissolved } \\
\text { Iron }\end{array}$ \\
\hline \hline 1 & 1.26 & 0.81 & 0.21 & 0.07 & 0.34 & 0.04 \\
\hline 2 & 1.28 & 0.84 & 0.14 & 0.10 & 0.23 & 0.07 \\
\hline 3 & 10.0 & 8.2 & 0.45 & 0.20 & 0.99 & 0.22 \\
\hline 4 & 0.18 & 0.04 & 0.13 & 0.03 & 0.17 & 0.09 \\
\hline 5 & 6.7 & 4.6 & 0.34 & 0.22 & 0.52 & 0.38 \\
\hline
\end{tabular}

Table II. Comparison of Total Iron and Dissolved Iron (mg/L)

\subsection{CONCLUSIONS}

Elevated iron concentrations in the SPWTF effluent primarily result from carryover of solids from the clarifier to the F-2 tank, the F-2 tank to the effluent line, and possibly from solids that collect the effluent line. Several factors are the cause of solids in the plant and clarifier effluent streams. Accumulation of solids in the pipe between the F-2 tank and the overflow weir are evident from visual inspection. Scale buildup between the clarifier plates, contributing to increased flow velocity between the plates and corresponding reduced settling capacity, has been observed. Lack of attention to the polymer setting during changing plant conditions can result in poor floc formation and consequent clarifier inefficiency. Limited jar testing has already shown that close attention to polymer settings can improve removal of solids.

However, even with maintenance improvements and closer attention to the operating characteristics of the Lamella clarifier, continual changes in plant chemistry and flow make it unlikely that the desired solids removal efficiency can be consistently achieved using the existing system. A permanent upgrade to the system involving filtration equipment will improve the reliability of control over iron removal.

The composition of the solids being pumped from the basins is unknown. Since polymers work best to remove colloidal particles, discrete particles (e.g., coal fine and rust flecks) may be unaffected by polymer interaction. It is unclear how completely the clarifier acts to settle unflocculated particles. Further studies of the solids in the basins and their effect on the treatment process are suggested. 
Other factors that may contribute solids are chemical and mechanical shocks to the system. Abrupt changes in basin chemistry, system chemistry, or system flow can cause a burst of iron containing material "hiding out" in system components.

\subsection{RECOMMENDATIONS}

Recommendations $1,2,3$, and 4 will improve operating efficiency, but by themselves will not correct all the problems causing iron to be discharged as solids or redissolved solids. Item 5 was not a problem during the study period, but is mentioned since it is critical to ensuring that ferrous iron removal does not become a problem.

1. Continue to develop expertise in evaluating polymer dosages under changing plant conditions. Accurate polymer settings will maximize clarifier efficiency.

2. Periodically have basin sludge removed to maximize retention volume and minimize solids pumped into the SPWTF process.

3. Minimize the impacts of changes to wastewater chemistry and flow rate.

a. Employ frequent short periods of pumping from the south to the north basin instead of infrequently pumping larger volumes.

b. When possible, route steam plant discharges to the south basin to dilute the water in the south basin and make it less likely to cause treatment difficulties.

4. Continue investigating use of chemical descaling agents and the possibility of clarifier plate replacement.

5. Monitor and maintain clarifier $\mathrm{pH}$ greater than 10.4 .

6. Engineer and install a finishing phase in the SPWTF process. Installing a finishing filter, pump, surge tank, and surge tank level-control valve between the clarifier and the F-2 tank is one possible solution. Such a system would improve the iron removal capability of the system and facilitate the removal of ferrous hydroxide, should it redissolve in the F-2 tank. Installation of a finishing filter and associated equipment would have beneficial effects on system operation. Specifically, it would:

a. Back up the clarifier and compensate for imprecise polymer settings.

b. Minimize buildup of iron-containing material upstream of the discharge weir.

c. Remove particulates which may not be detected by the operator colorwheel test for iron.

d. Minimize total suspended solids. 


\subsection{REFERENCES}

1. J. J. Morgan and W. Stumm, Aquatic Chemistry, 2nd ed., John Wiley \& Sons, 1981, Canada.

2. O. M. Aly and Samual D. Foust, Chemistry of Water Treatment, Butterworth 1983, Boston. 